\title{
The Shield of Achilles and the Temple of Venus
}

\author{
Stephen Lee Schwartz \\ João Pedro Mendes \\ Universidade de Brasília
}

SCHWARTZ, S. L. and MENDES, J. P. The Shield of Achilles and the Temple of Venus. Classica, Belo Horizonte, 3:108-117, 1990.

RESUMO: As diferenças entre a epopéia e o romance podem ser ressaltadas através da comparação da descrição do escudo de Aquiles, na Ilíada de Homero, e do Templo de Vênus em The Knight's Tale de Chaucer. Homero escreveu sobre o que definimos como detalhes da vida diária em situações contemporâneas das origens do poema; Chaucer, pelo contrário, transpõe os artifícios do amor cortês medieval para uma elaborada versão da mitologia grega: especificamente, a corte de Teseu em Atenas, transformada de tal modo que pareceria estranha a um grego da época clássica. Isso não significa que a epopéia é mais realista que o romance, mas que a epopéia é menos artificial e menos fantástica que o romance em sua visão de mundo.

One cannot hope to even indicate the difference between epic and romance by using just two poems; stil less by using just two examples from these poems; however, this is what is attempted in this essay. Using the description of the shield of Achilles ${ }^{1}$ from

1

The description of the shield of Achilles (Iliad, XVIII, 468-617) is a genuine synthesis of Greek life and culture of the time. The god Hephaestos forges a five-fold shield which depicts the earth, the heavens and the sea and all that they contain: marriage scenes, justice being dispensed, farming, merrymaking. The handiwork of Hephaestos is equivalent to the creative art of the poet. (See W. Marg, Homer ïber die Dichtung: Der Schild der Achilleus [Münster, 1971], 2nd. ed.). 
Homer's Illiad and the description of the temple of Venus from Geoffrey Chaucer's "The Knight's Tale" ${ }^{2}$ one hopes that at least one element both of epic and romance style will be revealed.

Chaucer in "The Knight's Tale" was the inheritor of both the epic and the romance traditions. The main source for "The Knight's Tale" was the Teseida of Boccaccio, a poem that deliberately employs epic machinery and which derives, in part, from a work of the epic writer Statius. Chaucer eliminated a large part of the Teseida's epic machinery in writing his version of the Palamon-Arcite story, ${ }^{3}$ but retained a framework of epic conventions although much of the significance of these conventions has been changed by the insertion

2

The knight is of the highest social level among the Canterbury pigrims; therefore his story is the first of Chaucer's Canterbury Tales.

3

After Theseus conquers Thebes, Palamon and Arcite, princes of that city, are found wounded, taken to Athens and are held without ransom. From their prison they see Emily, sister of Hippolyte, queen of the Amazons, whom Theseus has recently defeated and married; they both fall in love with her. Thus, the two cousins and friends become enemies. Arcite is later released as a favor to Theseus' friend Perotheus on condition that he never return to Athens on pain of death. Nevertheless, receiving a command from Mercury, Arcite goes in desguise to Athens and, by chance, becomes page to Emily and, later, squire to Theseus. After seven years, Palamon escapes from prison and hides in a grove waiting for nightfall to flee to Thebes. Arcite passes by lamenting his love for Emily and Palamon challenges him. A duel is planned but they are discovered by Theseus while they are fighting. Heeding the pleas of Hippolyte, Emily and their women retainers, Theseus pardons the two and sets a date for armed combat between them and their allies one year hence. The winner will have Emily as his bride.

Theseus builds a theater especially for this battle. The night before Palamon prays to Venus, in her temple that he may win Emily. Arcite prays to Mars that he may win the fight and Emily prays to Diana that she may be won by whoever loves her best. All the prayers are received favorably by the gods who are left to figure out how they may be granted since they seem contradictory. Saturn says that he will resolve the problem. In the battle, Arcite and his party defeat Palamon and his followers, but Arcite is mortally wounded when he is thrown by his horse at the instigation of Venus and Saturn. Palamon, who had been the first to see and fall in love with Emily marries her. Arcite is given a splendid funeral.

The battle-theater Theseus orders to be built for the combat between Palamon and Arcite has three temples within its walls: the temple of Venus at the eastern gate, the temple of Mars at the western and the temple of Diana at the northern gate. The temple of Venus, containing a statue of Verus which receives and gives the goddess's answers to prayers also contains paintings and relief sculpures showing, for the most part, the pains and sufferings necessary to or caused by love. This fits into courtly love tradition, but the extreme emphasis on the pain and tragedy of love shows only ane side of the concept. In C. S. Lewis's description, 
of the subject-matter of romance, ie, courtly-love conventions. Chaucer had employed romance-conventions before in his version of the first part of The Romaunt of the Rose, The Book of the Duchess, The House of Fame, and The Parliament of Fowls. These poems employ a fantastic and/or other-worldly atmosphere (that of a dream-vision in many of these cases) with courtly-love conventions and the literary and social conventions of chivalry.

The most generalized element of romance in "The Knight's Tale" is the courtly love convention. Although by no means conventionalized, the tale could not exist in anything approximately the same way without this. Yet the poem must be read with a knowledge of Greek mythology on the part of its readers. Theseus is portrayed with at least the outline of his legendary career in mind, and, since the fortunes of Palamon and Arcite are determined by Theseus' attack on Thebes, the story and the characters emerge from and are seen against a mythological background.

[the lover] is no light-hearted gallant: his love is represented as a despairing and tragical emotion - or almost despairing, for the is saved from complete [vain hope] by his faith in the god of love who never betrays his faithful worshippers and who can subjugate the cruelest beauties.

C. S. Lewis, The Allegory of Love: A Study in Medieval Tradition (New York: Oxford University Press), 1958, p. 3.

It is much closer to Lewis's summary of a passage from Chretien de Troyes' Lancelot:

Lancelot sets out to find the Queen and almost at once loses his horse. In this predicament he is met by a dwarf driving a tumbril. To his questions, the dwarf - surly like all of his race - replies, 'Get in, and I will bring you where you shall have news of the Queen.' The knight hesitates for a moment before mounting the cart of shame and thus appearing a common criminal; a moment later he obeys. He is driven through streets where the rabble cry out upon him and ask what he has done and whether he is to be flayed or hanged. He is brought to a castle where he is shown a bed that he must not lie in because he is a knight disgraced. He comes to the bridge that crosses into the land of Gorre - the sword bridge, made of a single blade of steel - and is warned that the high enterprise of crossing it is not for one so dishonoured as he. 'Remember your ride on the cart,' says the keeper of the bridge. Even his friends acknowledge that he will never be rid of the disgrace. When he has crossed the bridge, wounded in hands, knees and feet, he comes at last into the presence of the Queen. She will not speak to him... (op. cit., p. 27).

When she does speak, Guinevere wants to know why Lancelot had hesitated before getting into the cart (!).

See also Lewis's chapter on Chaucer. (op. cit., pp. 157-187). 
The Thebean war, interestingly enough, is instigated in this tale by the supplication of women ${ }^{4}$ not, as in the myth, by Adrastus, one of the original seven heroes. 5 This change in the myth is significant as it is another indication of the all important role of women in the romance conventions of courtly love (as opposed to the subordinate role of most earthly women, ie, all those who are not goddesses, demi-goddesses or the chosen lovers of the gods ) . As the supplications of women were able to persuade Theseus to attack Thebes, so are they able to prevent Theseus from executing Palamon and Arcite:

And on hir bare knees adoun they falle, And wolde have kist his feet ther as he stood:

Til at the laste aslaked was his mood, For pitee renneth soone in gentil herte. ${ }^{6}$

Women plak a powerful role in these heroes' lives: as suppliants they are able to influence affairs of state; as objects of love they are able to influence the course of human happiness - following, for the most part, courtly-love conventions.

But the most important element, partially belonging to courtlylove and partially to romance, is the temple of Venus episode. There are actually three temples dedicated to Venus, Mars and Diana respectively. On entering the temple of Venus one first sees the sufferings caused by and the follies of love:

First in the temple of Venus maystow se Wroght on the wal, ful pitous to biholde, The broken slepes, and the sikes colde,

4

Geoffrey Chaucer, «The Knight's Tale,» The Works of Geoffrey Chaucer, ed. F. N. Robinson (Cambridge-Mass.: Houghton Mifflin Co., 1957), lines 894-897. All further references to «The Knight's Tale» will be from this edition and will be placed in the text.

5

See Robert Graves, The Greek Myths, II (New York: George Braziller, 1957), pp. 15-21.

6

The change is in Boccaccio and is followed by Chaucer. Evidently the version of the myth used in the Teseida was a combination of two myths about the attack on Thebes. Theseus captured the city but did not kill Creon. This was done by the Epigoni, sons of the Seven against Thebes, who swore to avenge their fathers. See Robinson, p. 671, note for lines $983 \mathrm{ff}$., and Graves, pp. 21-4. 
The sacred teeris, and the waymentynge,

The firy strokes of the desirynge

That loves servantz in this lyf enduren;

Tho othes that hir covenantz assuren;

Plesaunce and Hope, Desir, Foolhardynesse,

Beautee and Youthe, Bauderie, Richesse,

Charmes and Force, Lesynges, Flaterye,

Despense, Bisyness, and Jalousye,

That wered of yelewe gooldes a gerland,

And a cokkow sittynge on hir hand...

(1918-1930)

The pains and delusions of love are of course real, but the style of this portrayal is in terms of personification and fantasy. There is no simple retum to Greek mythology (and, certainly, no question of historically accurate depiction). Greek, Roman and Old Testament worlds are all mixed together:

Nat was foryeten the porter, Ydelnesse, Ne Narcisus the faire of yore agone, Ne yet the folye of Kyng Salomon, Ne yet the grete strenghte of Ercules.

(1940-1943)

All this comes from the author, Chaucer, and his models, but in terms of literary convention the mixture of Greek and Roman mythology with King Solomon, the allegory and personification and the satiric figure of Jealousy with a cuckoo (symbol for cuckold) in ther hand - to mention just one example - comes from the knight who is telling the story and who was, even though a composite figure and an idealization of knighthood, a real, ie, a historical, personage. The knight puts the characteristics accruing to the courtly love conventions of his own day into the past of Theseus and Thebes. And a very mixed past it is at that.

Venus herself, or rather her statue through which the goddess makes a sign of her assent to Palamon's prayer, is described in a similar manner: 
The statue of Venus, glorious for to se, Was naked, fletynge in the large see, And fro the navele doun al covered was With wawes grene, and brighte as any glas. $A$ citole in hir right hand hadde she, And on hir heed, ful semely for to se, $A$ rose gerland, fressh and wel smellynge: Above hir heed hir dowves flikerynge. Biforn hire stood hir sone Cupido; Upon his shuldres wynges hadde he two, And blynd he was, as it is often seene; $A$ bowe he bar and arwes brighte and kene.

(1955-1966)

The combination of the grotesque and the lovely, the satiric and the emotionally true, the allegoric and the mythological can also be seen in the descriptions of the temples of Mars and Diana, especially in that of Mars:

Ther saugh I first the derke ymaginyng

Of Felonye, and al the compassyng;

The crueel Ire, reed as any gleede;

The pykepurs, and eek the pale Drede;

The smylere with the knyf under the cloke;

The shepne brennynge with the blake smoke;

The tresoun of the mordrynge in the bedde;

The open werre, with woundes al bibledde;

Contek, with blody knyf and sharp manace.

Al ful of chirkyng was that sory place.

(1995-2004)

The statue of Mars upon a carte stood Armed, and looked grym as he were wood; And over his heed ther shynen two figures of sterres, that been cleped in scriptures, That oon Puella, that oother Rubeus This god of armes was arrayed thus. $A$ wolf ther stood biforn hym at his feet With eyen rede, and of a man he eet; 
and it is the temple of Mars that is closest to at least one of the descriptions on the shield of Achilles:

and Hate was there with Confusion among them, and Death the destructive;

she was holding a live man with a new wound, and another

one unhurt, and dragged a dead man by the feet through the carnage.

The clothing upon her shoulders showed strong red with the men's blood.?

Confusion red with blood dragging a live, unwounded man, a freshly wounded man and a dead man behind her is fit company for the wolf gnawing a dead body at Mars' feet; however, there is no place on the shield for the pickpocket and the smiler with his hidden knife, not even in the city scenes.

Achilles' shield represents the world of Homer's epic: the society of the heroic age: it is idealized (as the whole idea of a heroic age is an idealization), but it neither forgets nor substitutes the everyday realities by the fantastic or the grotesque:

There were three sheaf-binders who stood by, and behind them

were children picking up the cut swathes, and filled their arms with them

and carried and gave them always; and by them the king in silence

and holding his staff stood near the line of the reapers, happily.

And apart and under a tree the heralds made a feast ready

and trimmed a great ox they had slaughtered. Meanwile the women

scattered, for the workmen to eat, abundant white barley.

(554-560)

7

Homer, The Iliad, trans. Richmond Lattimore (Chicago: The University of Chicago Press, 1957), XVIII, 535-538. All references will be from this translation and will be placed in the text. 
... These

wore, the maidens long light robes, but the men wore tunics

of finespun work and shining softly, touched with olive oil.

And the girls wore fair garlands on their heads, while the young men

carried golden knives that hung from sword belts of silver.

At whiles on their understanding feet they would run very lightly,

as when a potter crouching makes trial of his wheel, holding

it close in his hands, to see if it will run smooth.

The "everyday" elements (not "realistic" since this word pertains to style) are the order and arrangement of the reapers, binders and gleaners; the location of the king, near the field but apart from the farm-workers, clearly indicating superiority, and the "white barley" that is scattered for the workmen. In the dance scene, these elements are, even more than the dance itself, the "tunics of fine-spun work and shining softly, touched with olive oil," the decorations of garlands, golden knives and silver sword-belts, and, certainly, the movements of the potter at his wheel.

The descriptions on the shield are obviously meant to present an entire earthly world; it does not matter whether the descriptions themselves were written or altered at different times, whether the shield episode was part of the "original" lliad, or even whether they were all written or not by the same poet - after all Chaucer's knight's story is a compilation by Chaucer of material from different sources, many of them previously written poems in different languages by earlier poets.

The world of the Iliad begins with the earth, sky, the sea; the sun, moon and the constellations, and ends with "... the great strength of the Ocean River/which ran around the uttermost rim of the shield's strong structure." (I. 606-607). No one today 
accepts this description as geographically accurate, but it completes a cycle started at the beginning of the shield's description, and, as such, is a satisfying conclusion. And it is in the comparisons of Homer's and Chaucer's descriptions (for chaucer's description is also a description of world, not the knight's world, but the world of courtly love and medieval romance) that can be found elements which partially define epic and romance. Homer idealizes routine, everyday actions, but, in spite of the idealization, these actions are still a part of his world (or so we must assume). Chaucer's knight, however, combines courtly love conventions of his own day (which, in themselves, were not everyday realities) with a fantastic ${ }^{8}$ world based on adaptation of Greek mythology, which was, again, not part of his own world, nor Chaucer's; was not their own reality. The former is epic; the latter, romance.

Yet for all the grotesque contained in the literary descriptions, Chaucer's and Homer's worlds were perhaps more satisfying than the modern day's conception of itself - no matter what historians may say about the primitiveness of these epochs:

The thin-lipped armourer, Hephaestos hobbled away,

Thetis of the shinning breasts

Cried out in dismay

At what the god had wrought

To please her son, the strong

Iron-hearted man-slaying Achilles

Who would not live long. ${ }^{9}$

8

See W. P. Ker, Epic and Romance: Essaks on Medieval Literature (New York: Dover Publications, Inc., 1957), p. 4: «Romance means nothing if it does not convey some notion of mystery and fantasy.»

9

W. H. Auden, «The Shield of Achilles», last stanza, in Collected Shorter Poems - 1927-1957 (New York: Random House, Inc., 1966), pp. 294-295. Auden uses scenes from Homer's depiction of Achilles' shield to portray the horrors found in modern life. 


\section{A LIST OF WORKS CONSULTED}

ABERCROMBIE, Lascelles. The Epic. New York: Oxford University Press, 1922 .

AUDEN, W. H. Collected Shorter Poems - 192\%-195\%. New York: Random House, 1966.

CHAUCER, Geoffrey. The Works of Geoffrey Chaucer, ed. F. N. Robinson. Cambridge-Mass.: Houghton Mifflin Co., 1957.

FROST, William. «An interpretation of Chaucer's Knight's Tale» in: Chancer Criticism: The Canterbury Tales, ed. Richard Schoek and Jerome Taylor. Notre Dame-Indiana: University of Notre Dame Press, 1960.

GRAVES, Robert. The Greek Myths. 2 vols. in one. New York: George Braziller, 1957 .

HAM, Edward B. «Knight's Tale». $E L H$, XVII (Dec. 1950), 252-261.

HOMER. The Iliad, trans. Richmond Lattimore. Chicago: The University of Chicago Press, 1957.

- Iliade. Texte etabli e traduit par Paul Mazon. Paris: «Les Belles Lettres», tome III, 1956.

KER, W. P. Epic and Romance: Essays on Medieval Literature. New York: Dover Publications, Inc., 1957. Reprint of the 1926 edition.

LEWIS, C. S. The Allegory of Love. A Study in Medieval Tradition. New York: Oxford University Press, 1958. First published, 1936.

MARG, W. Homer über die Dichtung: Der Schild der Achilleus. Münster, 2nd. ed., 1971. 